\title{
Light interception and yield response of cotton varieties to high density planting and fertilizers in sub-tropical India
}

\author{
M. Y. Ajayakumar, M. R. Umesh*, Shivaleela and J.M. Nidagundi \\ Sciences, Raichur-584104 (Karnataka), INDIA \\ *Corresponding author. E-mail: mrumeshagri@gmail.com \\ Received: September 11, 2016; Revised received: February 17, 2017; Accepted: August 25, 2017
}

All India Coordinated Research Project on Cotton, Main Agricultural Research Station, University of Agricultural

\begin{abstract}
Plant density and optimum fertilization are two important agronomic practices to enhance productivity of cotton (Gossypium hirsutum L.) varieties. The objective of this study was to investigate the effect of high density planting (HDPS) and fertilization rate, especially their interactions, on yield, yield components of cotton varieties in sub-tropical India. Split-split plot design was adopted and replicated thrice. The main plots were assigned to low, medium and high plant densities $\left(16.7,13.3\right.$ and 11.1 plants $/ \mathrm{m}^{2}$ ). Pre released cotton varieties $\mathrm{TCH}-1705$ and $\mathrm{LH}$ 2298 were tested in low, moderate and high rates of fertilizers recommended for the region $(100,125$ and $150 \%)$ in sub-sub plots. Significantly higher seed cotton yield $(1148 \mathrm{~kg} / \mathrm{ha})$ was achieved in narrow inter row spaced at $60 \mathrm{~cm}$ over normal plant row spacing of $90 \mathrm{~cm}(1025 \mathrm{~kg} / \mathrm{ha})$. Compact genotype TCH-1705 was out yielded $(1146 \mathrm{~kg} / \mathrm{ha})$ over LH 2298(1044 kg/ha). Application of fertilizers at higher rate improved seed cotton yield (1232 kg/ha) Leaf area index (3.8) and light interception (0.98) over blanket recommendation. The results of the study inferred that seed cotton yield improvement was possible under HDPS production system with compact varieties grown at narrow spacing and higher fertilizer dose.
\end{abstract}

Keywords: Cotton, Leaf area index, Light interception, Plant density

\section{INTRODUCTION}

Cotton growing areas of India is characterized by high input responsive, increased cost of production and susceptibility of Bt-Cotton hybrids to minor pests. Increasingly, seed costs have become a larger percentage of the overall input costs for cotton production, largely because of the technology development associated with the various transgenic traits (AICCIP Annual Report, 2014).

The adoption of high density planting system (HDPS) along with good fertilizer management and better genotypes is a viable approach to break the current trend of stagnating yields under primarily rainfed hirsutum cotton growing areas of India. A proper space between plants and row spacing is a key agronomic factor to optimize the resource use and enhance crop productivity. Altered plant density and crop geometry is a time tested agronomic technique to improve yield and profitability (Venugopalan et al., 2013). Establishing an appropriate plant stand is paramount to obtain high yields as lower plant density will be wastage of resources while high plant density limits individual plant growth (Brodrick et al., 2010). Plant density directly influences the radiation interception, moisture availability, wind movement and humidity that in turn affect the canopy height, branching pattern, boll behavior, crop maturity and yield. Adequate plant den- sity facilitates the efficient use of applied fertilizers and irrigation. A decrease in row width resulted better light interception due to rapid canopy development and early canopy closure. The spirit of cotton crop management is to keep balance between vegetative and reproductive growth. The fertilizer use has played a crucial role in boosting the cotton productivity (Munir et al., 2015).

Light is the key role in net primary productivity, light availability varies with plant population spatial arrangements, especially with canopy structures. The variation in canopy light availability is a result of foliage structural and canopy architectural characteristics (Maddonni et al., 2001). In growing canopies, foliar traits (such as leaf area index and leaf mass per unit area) are the important factors in leaf light harvesting capacity and photosynthetic potentials. Generally, light interception varies with crop developmental stage. Dry matter production is always positively related to light interception.

After introduction of $B t$-cotton hybrids cotton productivity has jumped four folds in last decade. However, due to susceptibility of $B t$-cotton to pink bollworm, sucking pests attention has been made towards productivity improvement of cotton varieties. Among many options, seed cotton yield per hectare with enhanced fertilizer dose found profitable and viable (AICCIP Annual Report, 2014). Thus, the field study 
was formulated with an objective to investigate determine the impact of canopy on light interception in narrow-wide row planting pattern and performance of cotton varieties under high plant density and graded fertilizer levels.

\section{MATERIALS AND METHODS}

Experimental site: Field experiment was conducted at Main Agricultural Research Station, University of Agricultural Sciences, Raichur during the rainy season of 2015-16. Experimental site is situated in the North Eastern Dry zone of Karnataka at $16.6^{\circ}$ North latitude and $77.3^{\circ}$ East longitude with an altitude of $329.6 \mathrm{~m}$ above mean sea level. The experiment was laid out in a split-split plot design and replicated thrice. The soil in the experimental site was clay loam with low available nitrogen, medium available phosphorus (12.6 kg/ha) and high available potassium. The treatments consisted of three spacing $60 \mathrm{~cm} \times 10 \mathrm{~cm}\left(\mathrm{P}_{1}\right)\left(16.7\right.$ plants $\left./ \mathrm{m}^{2}\right)$, $75 \mathrm{~cm} \times 10 \mathrm{~cm}\left(\mathrm{P}_{2}\right)\left(13.3\right.$ plants $\left./ \mathrm{m}^{2}\right)$ and $90 \mathrm{~cm} \times 10 \mathrm{~cm}$ $\left(\mathrm{P}_{3}\right)$ (11.1 plants $\left./ \mathrm{m}^{2}\right)$. Densities were achieved by choosing the appropriate plant distance within a row, thus row distance was maintained. The traditional plant population is 5.5 plants $/ \mathrm{m}^{2}$. Cotton genotypes TCH1705 and LH-2298 were selected for the study as sub plot factor. There were three fertilizer levels 100, 125 and 150 per cent of the recommendation as sub-sub plot treatments. For cotton varieties 80:40:40 kg NPK/ ha was recommended for the experimental site region. Rest of the production practices were as per the university crop production guide for the region. The row orientation was east to west. Cotton was planted by hand dibbling on $21^{\text {st }}$ August, 2015. Each main plot contained 15, 12 and 10 rows for $\mathrm{P}_{1}, \mathrm{P}_{2}$ and $\mathrm{P}_{3}$ respectively rows of cotton, $4 \mathrm{~m}$ long with an inter-row spacing of $0.9 \mathrm{~m}$. The harvested at January 15 , February and final picking was on $15^{\text {th }}$ February, 2016. A basal fertilizer was applied at a rate of $40 \mathrm{~kg} \mathrm{~N}^{-1}$ and $40 \mathrm{~kg} \mathrm{ha}^{-1} \mathrm{P}$ and $\mathrm{K}$ and the other half was top-dressed at early flowering and boll initiation stage in two equal splits. The experimental plots were irrigated during dry spells with $50 \mathrm{~mm}$ water each time. A top fertilizer with 40 $\mathrm{kg} \mathrm{ha}^{-1} \mathrm{~N}$ was applied at the time of irrigation.

Determination of light interception: Radiation interception is calculated using the following relationship $\mathrm{F}=\left(1-\mathrm{I} / \mathrm{I}_{0}\right)$ where $F$ is the fractional amount of radiation interception, Iois the measured incident PAR on the surface of the ground, and $I t$ is the radiant flux density on top of the canopymeasured by using an SunScan Canopy analyzer (Delta-T, UK). The value of Io was estimated by considering longitude, latitude and sunshine hours as outlined in FAO Irrigation and Drainage PaperNo. 56. All measurements were recorded at 10:00 $\mathrm{h}$ to $14: 00 \mathrm{~h}$ in a clear sunny day at intervals of $\sim 7-15 \mathrm{~d}$, from 45 days after planting depending on weather conditions. PAR is assumed to be 0.48 times that of the total solar radiation (Monteith, 1977). The weather data were collected from an automatic weather station near the experimental field. The weather data of daily maximum and minimum temperature, daily incoming solar radiation and rainfall are shown in Fig. 1.

Data analysis: An analysis of variance (ANOVA) was performed using the statistical software OPSTAT. In the analysis, ANOVA was performed to determine treatment differences for effects of plant density, fertilizer, varieties and interaction. Least significant differences (LSD) were used to separate treatment means at the $5 \%$ level.

\section{RESULTS AND DISCUSSION}

Weather conditions: Environmental parameters including the rainfall, maximum and minimum temperature, and solar radiation during 2015 and 2016 was not much influence on cotton crop growth (Fig. 1.).Daily

Table 1. Seed cotton yield and ancillary data of compact hirsutum varieties as influenced by fertilizers and spacings under irrigated condition.

\begin{tabular}{|c|c|c|c|c|c|c|c|}
\hline Treatment Details & $\begin{array}{l}\text { Plant height } \\
\text { (cm) }\end{array}$ & $\begin{array}{l}\text { Monopo- } \\
\text { dia/ plant }\end{array}$ & $\begin{array}{l}\text { Sympodi- } \\
\text { al/ plant }\end{array}$ & $\begin{array}{l}\text { Bolls/ } \\
\text { Sq. m }\end{array}$ & $\begin{array}{l}\text { Boll } \\
\text { weight (g) }\end{array}$ & $\begin{array}{l}\text { Plant densi- } \\
\text { ty (No./plot) }\end{array}$ & $\begin{array}{l}\text { Seed cotton } \\
\text { yield (kg/ha) }\end{array}$ \\
\hline \multicolumn{8}{|l|}{ Spacings $(S)$} \\
\hline $\mathrm{P}_{1}: 60 \times 10 \mathrm{~cm}$ & 107.2 & 1.93 & 19.0 & 87.7 & 3.52 & 300.9 & 1148 \\
\hline $\mathrm{P}_{2}: 75 \times 10 \mathrm{~cm}$ & 115.3 & 2.09 & 21.0 & 72.1 & 3.61 & 228.1 & 1111 \\
\hline $\mathrm{P}_{3}: 90 \times 10 \mathrm{~cm}$ & 121.2 & 2.08 & 23.6 & 60.5 & 3.77 & 151.0 & 1025 \\
\hline $\mathrm{CD}(\mathrm{p}=0.05)$ & 3.4 & NS & 0.22 & 2.6 & 0.005 & 2.4 & 24.1 \\
\hline \multicolumn{8}{|l|}{ Varieties $(V)$} \\
\hline $\mathrm{V}_{1}: \mathrm{TCH}-1705$ & 101.3 & 2.04 & 23.1 & 77.1 & 3.74 & 226.8 & 1146 \\
\hline $\mathrm{V}_{2}:$ LH-2298 & 117.9 & 2.02 & 19.6 & 69.8 & 3.54 & 226.2 & 1044 \\
\hline $\mathrm{CD}(\mathrm{p}=0.05)$ & 5.6 & NS & 2.20 & 3.8 & 0.01 & NS & 69.5 \\
\hline \multicolumn{8}{|l|}{ Fertilizer doses $(F)$} \\
\hline $\mathrm{F}_{1}: 120: 60: 60 \mathrm{~kg} \mathrm{NPK} / \mathrm{ha}$ & 107.4 & 1.82 & 19.4 & 68.3 & 3.50 & 224.1 & 1005 \\
\hline $\mathrm{F}_{2}: 150: 75: 75 \mathrm{~kg} \mathrm{NPK} / \mathrm{ha}$ & 112.6 & 2.03 & 21.2 & 73.0 & 3.55 & 226.6 & 1047 \\
\hline $\mathrm{F}_{3}: 180: 90: 90 \mathrm{~kg} \mathrm{NPK} / \mathrm{ha}$ & 123.7 & 2.24 & 23.5 & 79.0 & 3.88 & 228.8 & 1232 \\
\hline $\mathrm{CD}(\mathrm{p}=0.05)$ & 10.9 & 0.10 & 1.87 & 7.0 & 0.32 & NS & 175.8 \\
\hline
\end{tabular}



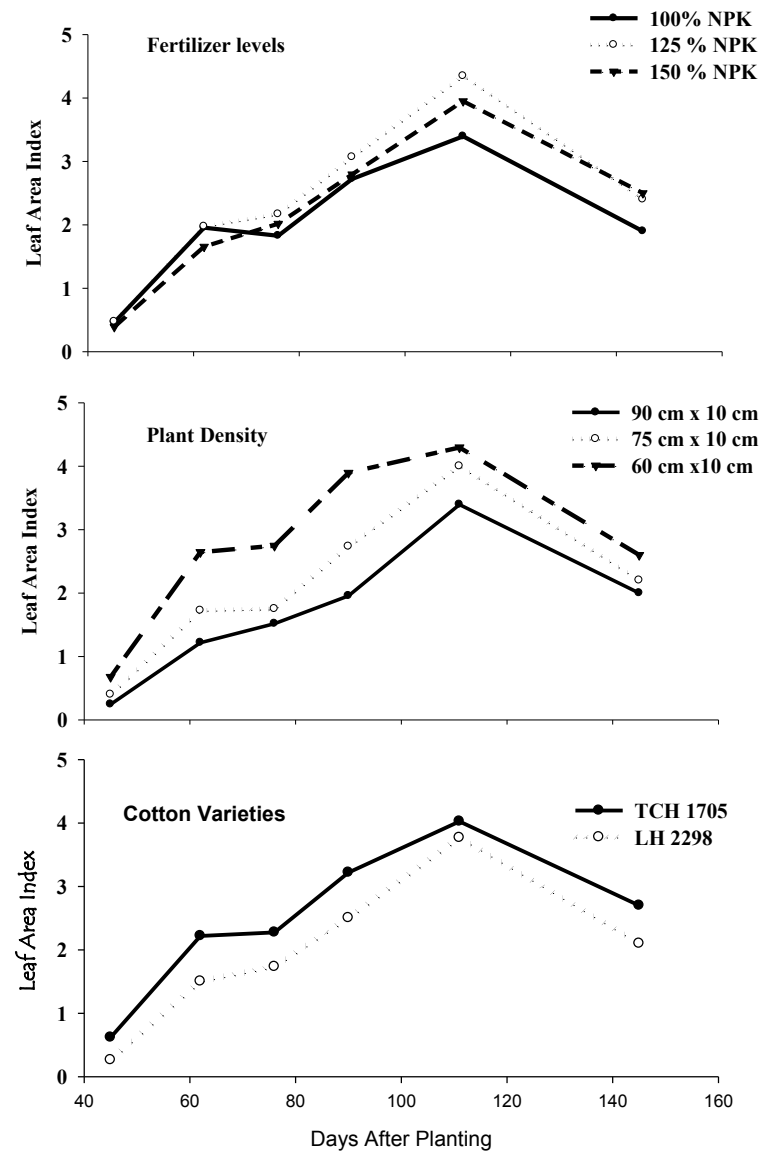

Fig.1. Leaf area index during growing season under fertilizer supply levels and planting geometry of cotton genotypes in Vertisols.

solar radiation reached a peak of $25 \mathrm{MJ} / \mathrm{cm}^{2} /$ day at the summer months and averaged $15 \mathrm{MJ} / \mathrm{cm}^{2} /$ day over the growing season. Seasonal precipitation during the experimentation period was similar to normal year. However, rainfall receded abruptly in mid-September and irrigation water available was provided to keep the trial stress free. Planting was delayed due to late onset of monsoon and non-availability of irrigation canal water. Temperature at planting was warm and good for quick establishment and early vigour of cotton crop. Minimum and maximum seasonal temperature trends were similar and followed long term trends.

Plant density: Row spacing is important in crop canopy structure (Andrade et al., 2002; Sharratt and Mc Williams, 2005). Leaf area index (LAI) increases with time; LAI increases until it reach its maximum value, and then it decreases gradually due to leaf senescence. Better canopy structure can result in better solar radiation interception, and consequently affect light availability. In wider spaced plants exhibited taller plants, more number of sympodial per plant, boll weight. However, significantly higher number of bolls per $\mathrm{m}^{2}$ and seed cotton yield was recorded in narrow spaced rows $(60 \mathrm{~cm} \mathrm{x} 10 \mathrm{~cm})$ over conventional planting pat-
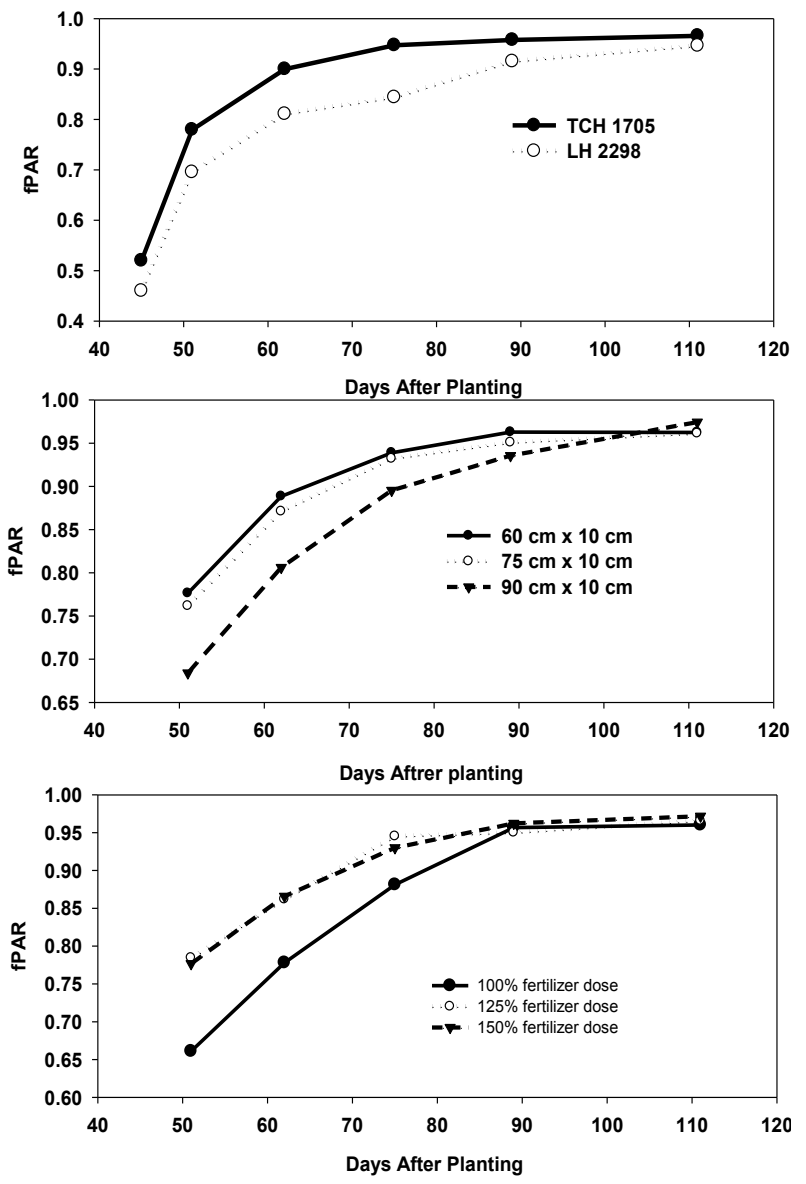

Fig. 2. Fraction of PAR intercepted during growing season under fertilizer levels and planting pattern of cotton varieties in Vertisols.

tern (Table 1). It was mainly due to enhanced light interception and LAI (Fig. 2). Due to higher plant density utilized all natural resources like solar radiation, moisture, nutrients and space. Maximum LAI increased photosynthesis and utilized for boll development, which ultimately improved the seed cotton yield. The taller plants, maximum leaf area index highest seed cotton yield were recorded with high density (2.22 lakh ha ${ }^{-1}$ ). Whereas, more sympodial branches, individual boll weight and bolls per plant were increased with decreased plant densities (Paslawar et al., 2015).

Genotypes: An ideal variety having better adaptation to high-density planting is the first step for successful HDPS. On Vertisols, two pre released genotypes were evaluated genotype TCH-1705 was found suitable for HDPS based on growth, yield and yield attributes (Table 1). It also recorded significant differences in sympodial branches, bolls per $\mathrm{m}^{2}$, boll weight over LH -2298. Significant increase in yield under high plant densities was higher in dwarf varieties with more determinate growth. Genotype that produce fewer, shorter and lower fruiting branches are ideal for high density planting. TCH-1705 was dwarf and more sympodial 
branches and boll weight were responsible for higher seed cotton yield over LH-2298 (Table 1). Silva et al. (2012) and Rossi et al. (2007) also observed significant interaction between plant density and genotype and recommended a density dependent selection of cotton genotypes. Further, this genotype was also showed higher light interception throughout the crop season indicate better canopy development and utilization of transmitted light (Fig.1). Earlier, Heitholt et al. (1996) observed that at equal densities with narrow row allowed each plant to intercept more light and increase seasonal light interception.

Fertilizer levels: A pertinent question to be resolved is whether the demand for nutrients is greater under HDPS since the plant population is higher. Significant difference in seed cotton yield up to $15-18$ per cent was recorded by application of 50 per cent higher over blanket recommendation of the region. Singh et al. (2012) are of the opinion that application of $25 \%$ additional fertilizers would be needed to meet the increased requirement of the crop under HDPS over conventional plant density. Further, Rinehardt et al. (2003) also indicated that $30 \%$ more $\mathrm{N}$ is required under ultra-narrow row cotton compared to the conventional row cotton. The plants grew taller and there was delay inmaturity with additional fertilizer dose. Venugopalan et al (2013) opined that application of higher dose of $\mathrm{N}$ to high density cotton increased immature bolls and delayed maturity.

Light interception (F): Cumulative intercepted PAR started from emergence up to harvest, which ranged from 14 to $21 \mathrm{MJ} \mathrm{m}^{-2}$ per day (Fig. 1). The differences in $F$ were significant among the planting patterns. In all the planting patterns, $F$ consistently increased until 105 days after planting (DAP). During this period, the highest $F$ was observed in narrow rowed $60 \mathrm{~cm} \times 10$ $\mathrm{cm}$ spacing as compared other row patterns. The maximum $F$ in $\mathrm{P}_{1}, \mathrm{P}_{2}$, and $\mathrm{P}_{3}$ was $0.879,0.980$, and 0.966 , respectively. After the canopy closed, the $F$ curve began to fit into a slow decline stage. Beyond 128 DAP, the smooth curve did not change for $\mathrm{P}_{2}$ and $\mathrm{P}_{3}$ but it fluctuated immediately for $\mathrm{P}_{1}$. The difference in $F$ among the planting patterns was significant the difference in $F$ of $\mathrm{P}_{1}$ from that of the other planting patterns was significant, whereas no significant difference between that of $\mathrm{P}_{2}$ and $\mathrm{P}_{3}$ were observed. After 105 DAP until harvest, $F$ in $\mathrm{P} 1$ was considerably lower than that in the others. In addition, a remarkably wide bare area between two narrow double rows was observed in P1; hence, $F$ was rather low at noon. In contrast, $F$ in P2 and $\mathrm{P} 3$ was greater at noon.

Leaf area index (LAI): Consistant expansion of cotton LAI over time was throughout the crop season (Fig. 2). For most crops, $F$ is highly dependent on LAI. Significant difference among planting patterns, genotypes and fertilizer levels was observed. The maximum LAI was achieved by application of $50 \%$ higher over blanket recommendation (F1). Application of 100, 125 and 150 percent of blanket was recorded LAI of 3.39, 4.34 and 3.95 respectively. While, narrow spaced canopy recorded significantly higher LAI over wider row spacing at 60 and $90 \mathrm{~cm}$ apart. Further, significant difference was observed between cotton genotypes lower LAI was observed in TCH 1705 (4.03) over LH-2298 (3.77). The LAI recorded in P1, P2, and P3 was3.39, 4.00 , and 4.29 , respectively. In all planting patterns, once the maximum LAI was attained, the value of LAI started to decline. Moreover, the rate of decline was quite similar across the patterns, cultivars and fertilizer levels.

\section{Conclusion}

Weather attributes like temperature, light intensity had not much influence on cotton crop growth. In the present study, high density planting systems (HDPS) in 60 $\mathrm{cm}$ inter row spacing and $10 \mathrm{~cm}$ within row at a plant density of 16.7 plants $/ \mathrm{m}^{2}$ was found superior over normal planting production system. With the aid of intensive practices and plant density needs 50 per cent more than recommended dose of fertilizers application was found significant improvement in seed cotton yield. Compact cotton genotype TCH -1705 was out yielded over LH -2298. The results suggest that this HDPS system of cotton production will be successful by selection of potential compact genotype grown in narrow row spacing with application of fertilizers higher than blanket for growing cotton under similar conditions to this experiment.

\section{ACKNOWLEDGEMENTS}

Authors are acknowledged ICAR-CICR, Coimbatore for financial support and service rendered by staff of Directorate of Research, University of Agricultural Sciences, Raichur, Karnataka and field crews of AICRP on Cotton, Main Agricultural Research Station, Raichur, Karnataka, India.

\section{REFERENCES}

AICCIP (2014) .All India Coordinate Cotton Improvement Project -Annual report 2013-14. Pub: Project Coordinator, Central Institute on Cotton Research, Regional Station, Coimbatore. Annual Report 2013-14

Andrade FH, Calvino P, Cirilo A, Barbieri P (2002) Yield responses to narrow rows depends on increased radiation interception. Agronomy Journal, 94: 975-980

Brodrick, R., MP.Bange, SP Milroy and GL Hammer, (2010).Yield and maturity of ultra-narrow rowcotton in high input production systems. Agronomy Journal. 102 (3): $843-848$

Heitholt, JJ, Meredith, WR, Jr. and Williford, JR, (1996). Comparison of cotton genotypes varying in canopycharacteristics in $76-\mathrm{cm}$ and $102-\mathrm{cm}$ rows. Crop Science. 36: $955-960$

Maddonni GA, Otegui ME, Cirilo AG., (2001).Plant population density, row spacing and hybrid effects on maize 
canopy architecture and light attenuation.Field Crop Research, 71: 183-193

Monteith, JL., (1977). Climate and the efficiency of crop production in Britain. Philosophical Transactions of the Royal Society B: Biological Sciences. 281:277-294

Munir, M. K., Tahir, M., Saleem M. F. and Yaseen, M. (2015). Growth, yield and earliness response of cotton to row spacing and Nitrogen management. The Journal of Animal \& Plant Sciences, 25(3): 729-738

Paslawar, AN, Deotalu, AS and PW Nemade (2015). High density planting of cotton variety $\mathrm{AKH}-081$ under rainfed condition of Vidharbha. Plant Archives.15 (2): 1075-1077

Rinehardt, JM, KL Edmisten, R. Wells, and JC, Faircloth (2003). Response of ultra narrow and conventional spaced cotton to variable nitrogen rates. Journal of Plant Nutrition. $27: 741-753$

Rossi,J., Eva Braojos, and Baxevanos, D. (2007). Varietal
Response to Ultra Narrow Row Cotton in Spain. World Cotton Research Conference 4. Sept 10-14, 2007, Lubbock, Texas. http://wcrc.confex.com /wcrc/2007/techprogram/ P1772

Singh JV, Shilpa Babar, Shalu Abraham, MV. Venugopalan, and G. Majumdar. (2012). Fertilization of High Density, Rainfed Cotton Grown on Vertisols of India. Better Crops with Plant Food. 96(2): 26-28

Sharratt, BS, McWilliams DA, (2005). Microclimatic and rooting characteristics of narrow-row versus conventional-row corn. Agronomy Journal. 97: 1129-1135

Silva PT, Macedo, FG, Camacho, MA, Santos, C, Santi, A, Krause, W. and Rambo. J. R. (2012). Spacing and plant density effect on reproductive development of herbaceous cotton - Scientia Plena8, 5 : 1-9

Venugopalan, MV, Kranthi, KV, Blaise, K., Shubhangi Lakde and Sankaranarayana, K., (2013). High density planting system in cotton -The Brazil experience and Indian initiatives. Cotton Research Journal,5 (2): 1-6 